\title{
Radiodating of the Hairs of the Presumed Holy Maria-Magdalena
}

\author{
Gérard Lucotte \\ Institut d'Anthropologie Moléculaire, Paris, France \\ Email: lucotte@hotmail.com
}

How to cite this paper: Lucotte, G. (2021). Radiodating of the Hairs of the Presumed Holy Maria-Magdalena. Archaeological Discovery, 9, 85-90.

https://doi.org/10.4236/ad.2021.92004

Received: January 13, 2021

Accepted: March 6, 2021

Published: March 9, 2021

Copyright $\odot 2021$ by author(s) and Scientific Research Publishing Inc. This work is licensed under the Creative Commons Attribution International License (CC BY 4.0).

http://creativecommons.org/licenses/by/4.0/ (c) (i) Open Access

\begin{abstract}
We report here the result concerning the radiodating of the carbon of the keratin of hairs from a lock of the presumed Holy Maria-Magdalena kept in the Saint-Maximin basilica. The aim of this research is to establish the best dating possible. The age obtained is $1260 \pm 30$ years; for this hair lock this date corresponds in fact to that of the exhumation of Maria-Magdalena's body by Charles II in 1279 . We conclude that King Charles II had completely carried out this exhumation story, to reinforce the influence of some part of his territory at that time.
\end{abstract}

\section{Keywords}

Maria-Magdalena's Hairs, Radiodating, Carbon of the Keratin, 1279 Exhumation, Charles II

\section{Introduction}

Holy Maria-Magdalena (3?-63?) is the most abundantly cited women in the four Gospels. According to the French "tradition des Saints de Provence" (Trouillet, 2016) she-and her companions landed on the present French Mediterranean shores (in a region corresponding to the current part of Les-Saintes-Maries-dela-Mer) and reached the towns of Marseilles and Aix-en-Provence. Details about the exhumation of the Maria-Magdalena's remains which are at the basis of this tradition are given by King Charles II (1248-1309), who exhumed these remains in 1279 (at this time he was only titled Prince of Salerne) near the "prieuré" (clergy house) of the village of Saint-Maximin.

Some relics of the presumed Maria-Magdalena were kept in the Saint-Maximin basilica, where a large lock of Maria-Magdalena's hair is conserved in a dedicated reliquary. I have obtained some hairs of this lock, for scientific purpose 
(microscopic examinations and chemical analyses). We have published these last year three initial papers: on the mitochondrial DNA haplogroup found by extracting genomic DNA from the bulb of hair number 10 (Lucotte, 2016), on the explanation of the observed brown-red colour of the hairs by scanning electron microscopic characterization of its melanosomes (Lucotte \& Thomasset, 2017), and on the description of some fennel rests on or at the vicinity of some of these hairs (Lucotte et al., 2018).

Remarkable results were obtained concerning a new protocol for radiocarbon dating of the keratin of hairs (Richardin et al., 2011). The research purpose of the present study is to use this sort of protocol for the radiocarbon dating of the keratin of three hairs of the presumed Maria-Magdalena.

\section{Material and Methods}

Figure 1 shows the three hairs used for the radiodating; they are the eleventh to thirteenth hairs of the kept lock.

These hairs of the lock were not studied for other thing that radiodating (they were only examined previously by optic microscopy), contrary to the ten first (Lucotte, 2016) that were analysed for electron microscopy and chemistry.

Radiodating of the ${ }^{14} \mathrm{C}$ of these hairs was carried out by the Company BetaAnalytic Inc. (Miami, USA). It is an original method of radiodating, consisting in the measurement of the carbon radioisotope of the keratin of the hairs.

\section{Results}

Figure 2 summarizes the results obtained for the radiocarbon dating; the calibration curve is intercepted by radiocarbon ages at the values of 1 or 2 sigmas. The 2 sigmas (95\% of probability) calibrated (Cal) results for the three values of the curve area: Cal AD (after J.-C.) 670 to 780, Cal BP (in radiocarbon years) 1280 to 1170; Cal AD 790 to 810, Cal BP 1160 to 1140; Cal AD850, Cal BP1100.

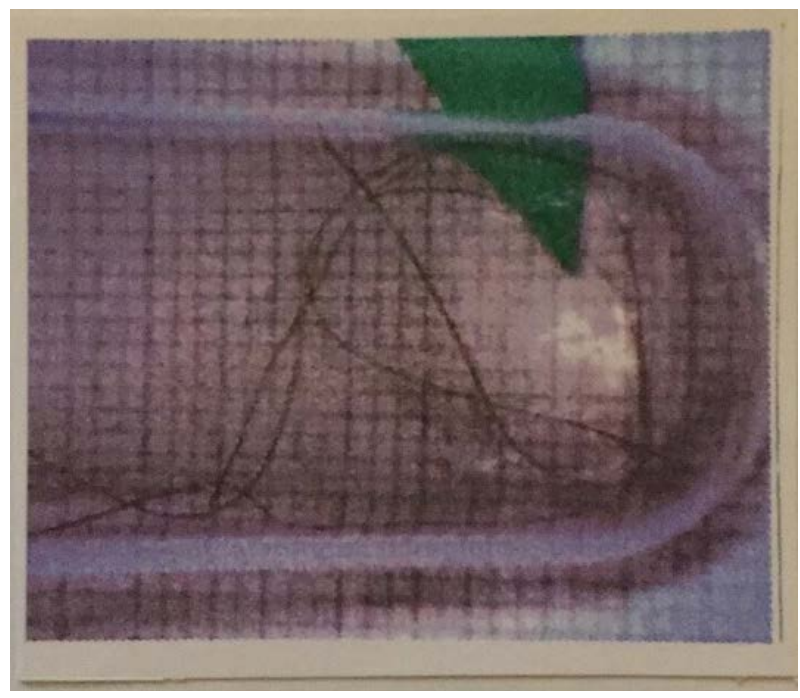

Figure 1. Photograph of three hairs used for the radiodating. 


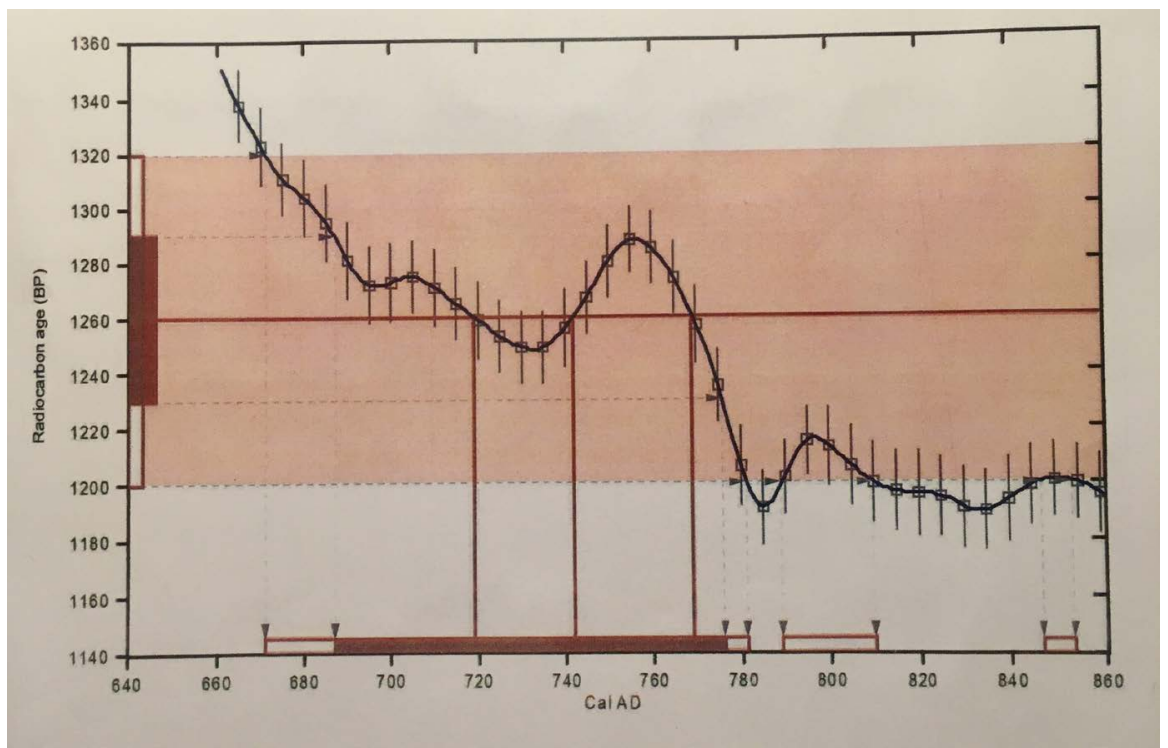

Figure 2. Calibration of radiocarbon age to calendar years.

Intercepts radiocarbon age with the calibration curve area: Cal AD720 (Cal BP1230); Cal AD740 (Cal BP1210); Cal AD 770 (Cal BP1180).

The 1 sigma (68\% of probability) calibrated results is: Cal AD 690 to 780 (Cal BP 1260 to 1170).

The final result for age is: $1260 \pm 30$ years. Remarkably these values correspond to 1279 , that is the date of exhumation of Maria-Magdalena's remains by Charles II.

\section{Discussion}

Results reported here on an original method of radiodating of the carbon of the keratin of the hairs establish that they are certainly not those of Holy Maria-Magdalena, who lived $\approx 3-63$. These hairs are kept in the Saint-Maximin basilica, and are known as those of the presumed Maria-Magdalena. Moreover, the date obtained (1260 \pm 30 years) corresponds to that (1279) of the exhumation of the presumed Maria-Magdalena by Charles II. He at that time-King (1248-1303) had indeed exhumed the body of the presumed Holy Maria-Magdalena in 1279, near the clergy House of the Saint-Maximin village.

The priest Etienne-Michel Faillon (1789-1870), a native of the Tarascon village, published in 1848 (Faillon, 1865) a monumental work of two volumes, totalling about 1500 pages with the goal to demonstrate by historical proof that Maria-Magdalena and her companions have truly lived in Provence at the first Century. But all the Failllon's arguments were systematically refuted in the middle of the XXth Century by Mgr Victor Saxer (Saxer, 1959); he claimed "Being the silence observed before 1279 at Saint-Maximin concerning Holy MariaMagdalena, we are well founded to say that she was not honoured in that site of Provence since the late period of the XIIIth Century".

As implication research of our own contribution to the question, we now ex- 
amined the "authentication proofs" concerning Maria-Magdalena's hairs we established in our previous publications.

In our second 2019 publication (Lucotte, 2019) we showed that deposits of calcium phosphate were observed on most of the hairs studied. We know that hairs covered the cranium in the historical (between 1283 and 1793) bust-reliquary where Maria-Magdalena's remains were kept; it is during this long period of time that the hydroxyapatite of the osseous cranium transferred to the hairs.

In the same publication we showed that there are some particles of gold (of a gold powder, some of them being of pure gold and other of an alloy of gold, silver and copper) on several of the hairs studied. Probably most of them (particularly those that are of pure gold) are due to close contact between hairs and the gold of the bust-reliquary (of gold) or/and of the crown of Charles I (Charles II's father) that was transferred to the hairs. Similarly particles of silver sulphide and chloride, of silver and gold and of silver and copper that we observed on the surface of some hairs studied were explained by the fact that these hairs (and other remains) were initially since 1281-kept in a silver reliquary.

In our 2018 publication (Lucotte et al., 2018) we established that fennel (Foeniculum vulgare) residues-pollen grains, foliar, pedicular and stem debris are found on, or at the proximity of some of the hairs studied. That confirms some details concerning the Maria-Magdalena discovery on 19 of December 1279, reported by Bernard Gui (Faillon, 1865) forty years after the facts.

But all these observations (about calcium phosphate, gold, silver and fennel) concern the remains exhumed in 1279, not Holy Maria-Magdalena per se.

In our second 2020 publication (Lucotte, 2020), we observed six marble particles on the surfaces of the hairs studied. These marble fragments are similar to those of the sarcophagis "de Marie-Madeleine" and "de Saint Sidoine" that one can see today in the crypt of the Saint-Maximin basilica. Our interpretation is that these marble fragments deposited on the surface of the hairs could originate from the walls of the sarcophagis and especially from the second one where we knew (Faillon, 1865) that Maria-Magdalena was buried before the 1279 exhumation. Our findings have some relative importance because previously (Fixot, 2009) there were in fact no formal proofs that Maria-Magdalena's body was buried initially in one or another of these sarcophagis.

Remains of the skeleton exhumed in 1279 mainly the cranium and the mandible, from Saint-Maximin; a fragment of tibia and some hairs, from La-SainteBaume; a piece of femur, from the Madeleine's church of Paris, were studied in a physical anthropology perspective (Saxer, 1977). The conclusions of this study agree more with that of an individual of the Mediterranean type, probably a woman, aged of about 50 years old.

What are the characteristics of the hairs from the body exhumed in 1279 ?

They are from a woman of maternal Jewish ancestry. This was established (Lucotte, 2016) by the amelogenin test and by mitochondrial DNA characteriza- 
tion on the genomic DNA extracted from the bulb of the hair number 10. Such a maternal Jewish ancestry was already worded in the Golden Legend (de Voragine, 2004), that was the main religious book which was largely diffused through Europe in the second half of the XIIIth Century.

They are of red-brown colour. This red coloration is not due to some sort of dyeing, but is the natural colour of the hair melanosomes (Lucotte \& Thomasset, 2017). The story of the corresponding lock of hair is somehow tortuous, but ever these hairs (located in transparent containers) were available to observers. That explains why the most famous representations of Maria-Magdalena concern paintings showing her with red-brown hairs (mainly from the XVth Century)

They are covered by marine remains (Lucotte et al., 2019). These remains: some mineral particles and micro-organisms (of vegetal and animal natures) adhering to the hairs, indicate a close past-contact of these hairs with the sea water. Such a finding is incompatible with that of Maria-Magdalena in the last period of her life, retired for thirty years in a cave of the mountains of the Sainte-Baume (Faillon, 1865).

These hairs were also covered by skin debris (Lucotte et al., 2020b): skin-cells, dandruffs, and other skin materials of various sorts like skin shreds. One of them (the hair number 9) is covered by a piece of scalp; it corresponds to the customary conservative procedure (with salt), that was probably used for the preservation of the precious skin tissue named the Noli me tangere (Faillon, 1865).

These hairs were also intensely infected by nits of louse (Lucotte et al., 2020a), a common complaint of adults in the past times.

\section{Conclusion}

The radiodating of the keratin carbon of the hairs kept in the Saint-Maximin basilica, which are from the presumed Holy Maria-Magdalena, has given in fact a date of $1260 \pm 30$ years. This date frames that of 1279, which was the exhumation of Maria-Magdalena by Charles II, King of Napoli and Count of Provence, Anjou and Maine. The significance of the present study is that it is highly probable that Charles II had completely fabricated this exhumation story, to reinforce the influence of one urban centre of his territory.

\section{Acknowledgements}

I thank F. Racine, the priest of the Saint-Maximin-la-Sainte-Baume basilica, who furnished Maria-Magdalena's hairs. Thank you also to Dr C. Patrick, Deputy Director of Beta Analytic, who provided precise information about this radiodating. I thank also the French association UNEC (W. Wuermeling) for financial support of this work.

\section{Conflicts of Interest}

The author declares no conflicts of interest regarding the publication of this paper. 


\section{References}

de Voragine, J. (2004). La légende dorée. Paris: Gallimard Ed.

Faillon, E. M. (1865). Monuments inédits sur l'apostolat de sainte Marie Madeleine en Provence, et sur les autres apôtres de cette contrée, saint Lazare, saint Maximin, sainte Marthe, les saintes Marie Salomé et Jacobé. Paris: Migne Ed.

Fixot, M. (2009). La crypte de Saint-Maximin-La-Sainte-Baume. Saint-Rémy-de-Provence: Edisud Ed.

Lucotte, G. (2016). The Mitochondrial DNA Mitotype of Sainte Marie-Madeleine. International Journal of Sciences, 5, 10-19. https://doi.org/10.18483/ijSci.1167

Lucotte, G. (2019). Silver and Gold on the Hairs of Holy Maria-Magdalena, Studied by Scanning Electron Microscopy and Elemental Analysis. Archaeological Discovery, 7, 257-282. https://doi.org/10.4236/ad.2019.74012

Lucotte, G. (2020). Mineral Particles Found on the Hairs of Holy Maria-Magdalena Studied by Scanning Electron Microscopy and Elemental Analysis. Open Journal of Applied Sciences, 10, 41-59. https://doi.org/10.4236/ojapps.2020.103004

Lucotte, G., \& Thomasset, T. (2017). Study of the Red Colour of Ste Marie-Madeleine $(\approx 3-63)$ Hair by Scanning Electron Microscopic Characterization of Its Melanosomes. Journal of Dermatology and Pigmentation Research, 1, 1-9.

Lucotte, G., D’Hérissart, E., \& Thomasset, T. (2019). Marine Micro-Remains on Holy Maria-Magdalena's Hair, Studied by Scanning Electron Microscopy and Elemental Analysis. Archaeological Discovery, 7, 155-191. https://doi.org/10.4236/ad.2019.73009

Lucotte, G., Izri, A., \& Thomasset, T. (2020a). Nits of Louse on the Hairs of Holy MariaMagdalena: A SEM-EDX Study. Global Dermatology, 7, 1-4.

Lucotte, G., Thomasset, T., \& Borensztajn, S. (2020b). Slin Debris on the Hairs of Holy Maria-Magdalean: A SEM-EDX Analysis. International Journal of Sciences, 9, 57-79. https://doi.org/10.18483/ijSci.2273

Lucotte, G., Thomasset, T., \& Salmon, A. (2018). Fennel (Foeniculum vulgare) Rests on the Holy Maria-Magdalena Hairs, Studied by Scanning Microscopy and Elemental Analysis. Archaeological Discovery, 6, 216-270. https://doi.org/10.4236/ad.2018.63012

Richardin, P., Gandolfo, N., Carminati, P., \& Walter, P. (2011). A New Protocol for Radiocarbon Dating of Hair and Keratin Type Samples-Application to an Andean Mummy from the National Museum of Natural History in Paris. Archaeological and Anthropological Sciences, 3, 379-384. https://doi.org/10.1007/s12520-011-0070-3

Saxer, V. (1959). Le culte de Marie-Madeleine en Occident, des origines à la fin du Moyen-Age. Auxerre: Society of Archaeological Digs of Yonne Ed.

Saxer, V. (1977). Les ossements dits "de sainte Marie Madeleine" conservée à SaintMaximin-la-Sainte-Baume. Provence Historique, 27, 257-311.

Trouillet, M. C. (2016). Les Reliques de Ste Marie-Madeleine. Aix-en-Provence: Petrus Ed. 